\title{
Cancer Recognition in Medical Image Processing using Watershed Algorithm
}

\author{
Sugumar V, Aravindasamy R, Jeffrin Rajan M, P. Kavitha
}

\begin{abstract}
Lung tumor is by all accounts the basic reason for death among individuals all through the world. Survival from lung tumor is straightforwardly identified with its development at its discovery time. The prior the identification is, the higher the odds of fruitful treatment.. To upgrade malignancy location the radiologists, utilizes CT check pictures for reviewing the insides of the body.Image handling methods give a decent quality apparatus to enhancing the manual examination. Henceforth, a lung malignancy recognition framework utilizing picture handling is utilized to arrange the present of lung disease in a CT-pictures. A programmed growth discovery framework is proposed to recognize malignant tumor from the CT check pictures. The tumor discovery conspire comprises of four phases. They are preprocessing, division, include extraction and characterization. These four levels are utilized as a part of picture handling to upgrade the tumor recognizable proof exactness. The ultimate result of this paper is to discover malignancy identification.
\end{abstract}

Keywords: Lung cancer,CT filter, preprocessing division, highlights extraction and grouping.

\section{INTRODUCTION}

The lungs are a couple of wipe with cone shape. The correct lung has three flaps and left lung has two projections. The correct lung is bigger than the left lung[25],[27],[29]. The oxygen is given to lung by breathing in process. The lungs tissue exchange oxygen to circulatory system. The lung growth is a sickness of unusual cells duplicating and developing into a tumor malignancy cells can be diverted from the lungs in blood. The lung growth regularly spread toward the focal point of the chest in light of the fact that the normal stream of lymph out of the lungs is toward the focal point of the chest. There are a few diverse sort of lung growth and these are isolated into fundamental two [1],[ 3],[5] classifications; little cell lung disease and non-little cell lung tumor which has three subtypes;

Carcinoma, Aden carcinoma and squalors cell Carcinomas. It is watched that lung growth positioned second among guys and tenth among females.

Revised Manuscript Received on July 22, 2019.

Sugumar V, Student, Department of IT, Bharath Institute of Higher Education and Research, Tambaram, India

Aravindasamy R, Student, Department of CSE, Bharath Institute of Higher Education and Research, Tambaram, India

Jeffrin Rajan M, Student, Department of CSE, Bharath Institute of Higher Education and Research, Tambaram, India

P. Kavitha, Department of IT, Bharath Institute of Higher Education and Research, Tambaram, India
The field of computerized demonstrative frameworks plays a crucial and indispensable role in the present era of electronic fully robotized living pattern. 596 Automated guidance framework for medical applications Image Processing are one such a field where different frameworks are suggested and still many more under theoretical plan due to today's hazardous innovation growth. To the extent that pixels with a comparable name share certain visual characteristics are known as the Image Division, the way to dol out a name to each pixel in a photo. Writing has an extensive variety of division strategies utilized as a part of lung tumor conclusion[2 ],[4],[6].

qualities is known as Image division. Writing has an extensive variety of division strategies utilized as a part of lung tumor conclusion[7],[9],[11].

Picture handling has wide degree in restorative picture preparing for diagnosing the Lung tumor. In our proposed framework portrayal of lung growth recognition framework that contains four essential stages. The principal arrange begins with taking a gathering of CT pictures (typical and strange) from the accessible Database from IMBA Home (VIA-ELCAP Public Access). The second stage applies a few procedures of picture improvement, to get best level of value and clearness [8],[ 10] ,[12]. The third stage applies picture division calculations which play a successful run in picture preparing stages, and the fourth stage acquires the general highlights from upgraded fragmented picture which gives pointers of typicality or anomaly of pictures.

\section{PROPOSED CONCEPT}

Our Proposed framework incorporates two modules preparing and testing .In Training module the trimmed CT check picture is contribution to the framework, trailed by Pre-Processing to improve the picture. In following stage highlights are separated and gone to SVM Classifier[37],[39],[41].

In Testing module CT picture is sent to Pre-Processing stage and the second part is picture division to extricate the lung district and ROI .The third part is highlight extraction and choice to remove the principle highlights of the tumor.The last part is the classifier to separate the Detection of malignancy or not a growth .Below figure1 demonstrates the square graph of proposed lung disease identification framework[13], [15], [ 17]

Published By: 




Figure 1.Block diagram of lung cancer detection module

\section{A. Pre-Processing}

Restorative pictures are adulterated with commotion and curios because of body developments Preprocessing is done to expel undesirable clamor and it offers clearness to the pictures at this phase where separating is done to evacuate noise.In our proposed framework we are utilizing resize and Thus wiener s used to removenoise[14], [16], [18] .

\section{a) Wiener Filter:}

The goal of the Wiener sift is to clear through clamor that has undermined a flag. It depends on a measurable approach. Common channels are intended for a coveted recurrence reaction. [4] The Wiener channel approaches sifting from various point. One is expected to know about the ghostly properties of the basic flag and the clamor, and one looks for the LTI channel whose yield would come as near the first flag as could be expected under the circumstances. Wiener channels are portrayed by the accompanying.

- Assumption: flag and (added substance) commotion are stationary straight irregular procedures with known phantom attributes.

- Requirement: the channel must be physically feasible, i.e. causal (this necessity can be dropped, bringing about a non-causal arrangement).

- Performance criteria: least mean-square blunder.

\section{B. Segmentation}

Division is utilized to make the parcel or portion the in various area; here all through the venture we proposed the watershed Segmentation. The principle reason for watershed division is to discover the 'watershed lines' in a picture to isolate the unmistakable areas.

Bolster Vector Machines (SVMs) are[ 3] learning techniques used for ordering images. It considers the specified image database as two sets of vectors in a "n" dimension room and creates an isolating hyper plane that increases the edge between the images that are important to investigation and the images that are not relevant to the issue. SVM is a part approach that uses the piece of job The bit job used as part of the SVM is highly important when it comes to the execution decision. An extreme edge classifier is the vital standard of SVMs. The data can definitely be mapped to a high-dimensional bit room first by using the part approaches. In the bit space, the most extreme edge classifier is resolved and the choice capacity of the comparing SVMs can be non-direct in the first space. The SVMs group the non-straight information in the space of the element into direct information in the space of the portion. The purpose of the SVM arrangement method is to find an significant and perfect hyper plane isolation unimportant vectors bymaximizing the span of is grouped into direct information in portion space by the SVMs. The point of SVM arrangement technique is to locate an ideal hyper plane isolating important and unimportant vectors bymaximizing the span of the edge (between the two classes).

\section{RESULTS}

In this area clarifies the yield of the proposed framework well ordered. The info picture for the proposed framework is disease influenced CT [2] check picture of a patient. In the event that we input a CT filter picture which is not influenced by the growth our framework will dismiss the picture as not influenced .In Figure2 (a) demonstrates the information picture chose by the client to our proposed framework. In Pre-processingphase we resize and de-clamor the picture to expel the commotion utilizing wiener channel which is appeared in Figure2 (b) \&(c) . Third stage is division we perform watershed division whose outcomes are appeared beneath figure2 (d). After division and highlight extraction utilizing GLDM and SVM classifier for recognized disease tumor district. Disease district is recognized and growth area are appeared in figure2 (e) and (f). At long last the Output picture is shown in Figure2 $(\mathrm{g})$.

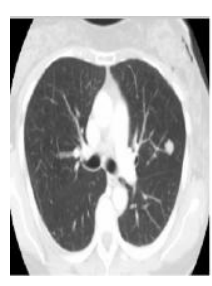

(a)

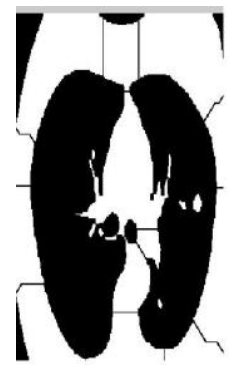

(a)

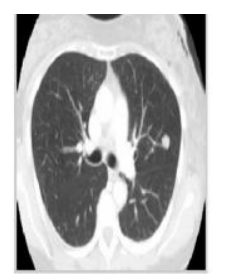

(b)

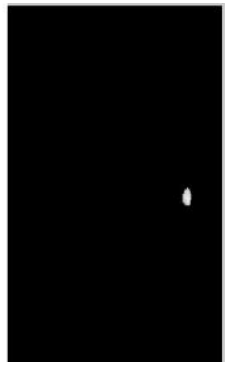

(b)

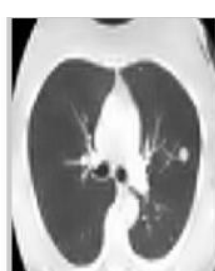

(c)

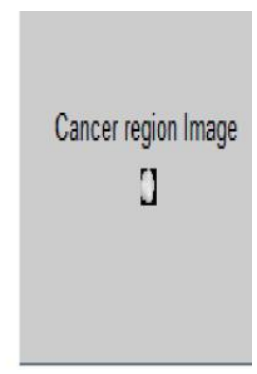

(c)

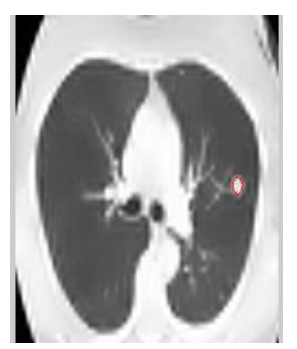

(g)

FIGURE2: (A) INPUT IMAGE, (B) RESIZED IMAGE, (C)DE-NOISED IMAGE,(D) WATERSHED SEGMENT 
IMAGE, (E) DETECTED CANCER REGION, SEGMENTED CANCER REGION IMAGE (G) MARKED CANCER REGION IMAGE.

\section{CONCLUSION}

This proposed framework tends to the picture preparing strategies to perceive the lung tumor in CT pictures. Our proposed framework builds up a programmed identification of lung malignancy in CT pictures utilizing watershed division, GLDM highlight and SVM classifier. Comparatively GLCM highlights give more precise outcomes than GLCM. The exactness of the tumor recognized is checked utilizing SVM order procedures.

\section{REFERENCES}

1 [1] Kumarave A., Rangarajan K.,Algorithm for automaton specification for exploring dynamic labyrinths,Indian Journal of Science and Technology,V-6,I-SUPPL5,PP-4554-4559,Y-2013

[2] P. Kavitha, S. Prabakaran "A Novel Hybrid Segmentation Method with Particle Swarm Optimization and Fuzzy C-Mean Based On Partitioning the Image for Detecting Lung Cancer" International Journal of Engineering and Advanced Technology (IJEAT) ISSN: 2249-8958, Volume-8 Issue-5, June 2019

[3] Kumaravel A., Meetei O.N.,An application of non-uniform cellular automata for efficient cryptography,2013 IEEE Conference on Information and Communication Technologies, ICT 2013,V-,I-,PP-1200-1205,Y-2013

[4] Kumarave A., Rangarajan K.,Routing alogrithm over semi-regular tessellations,2013 IEEE Conference on Information and Communication Technologies, ICT 2013,V-,I-,PP-1180-1184,Y-2013

[5] P. Kavitha, S. Prabakaran "Designing a Feature Vector for Statistical Texture Analysis of Brain Tumor" International Journal of Engineering and Advanced Technology (IJEAT) ISSN: 2249-8958, Volume-8 Issue-5, June 2019

[6] Dutta P., Kumaravel A.,A novel approach to trust based identification of leaders in social networks, Indian Journal of Science and Technology,V-9,I-10,PP--,Y-2016

[7] Kumaravel A., Dutta P.,Application of Pca for context selection for collaborative filtering,Middle - East Journal of Scientific Research,V-20,I-1,PP-88-93,Y-2014

[8] Kumaravel A., Rangarajan K.,Constructing an automaton for exploring Communication and Computing, ICRCC 2012,V-,I-,PP-161-165,Y-2012

[9] P. Kavitha, S. Prabakaran "Adaptive Bilateral Filter for Multi-Resolution in Brain Tumor Recognition" International Journal of Innovative Technology and Exploring Engineering (IJITEE) ISSN: 2278-3075, Volume-8 Issue-8 June, 2019

[10] Kumaravel A.,Comparison of two multi-classification approaches for detecting network attacks, World Applied Sciences Journal,V-27,I-11,PP-1461-1465,Y-2013

[11] Tariq J., Kumaravel A.,Construction of cellular automata over hexagonal and triangular tessellations for path planning of multi-robots,2016 IEEE International Conference on Computational Intelligence and Computing Research, ICCIC 2016,V-,I-,PP--,Y-2017

[12] Sudha M., Kumaravel A.,Analysis and measurement of wave guides using poisson method,Indonesian Journal of Electrical Engineering and Computer Science,V-8,I-2,PP-546-548,Y-2017

[13] Ayyappan G., Nalini C., Kumaravel A.,Various approaches of knowledge transfer in academic social network,International Journal of Engineering and Technology,V-,I-,PP-2791-2794,Y-2017

[14] Kaliyamurthie, K.P., Sivaraman, K., Ramesh, S. Imposing patient data privacy in wireless medical sensor networks through homomorphic cryptosystems 2016, Journal of Chemical and Pharmaceutical Sciences92.

[15] Kaliyamurthie, K.P., Balasubramanian, P.C. An approach to multi secure to historical malformed documents using integer ripple transfiguration 2016 Journal of Chemical and Pharmaceutical Sciences 92.

[16] A.Sangeetha,C.Nalini,"Semantic Ranking based on keywords extractions in the web", International Journal of Engineering \& Technology, 7 (2.6) (2018) 290-292 dynamic labyrinths,2012 International Conference on Radar,

[17] S.V.GayathiriDevi,C.Nalini,N.Kumar,"An efficient software verification using multi-layered software verification tool "International Journal of Engineering \& Technology, 7(2.21)2018 454-457

[18] C.Nalini,ShwtambariKharabe,"A Comparative Study On Different Techniques Used For Finger - Vein Authentication", International Journal Of Pure And Applied Mathematics, Volume 116 No. 8 2017, 327-333, Issn: 1314-3395

[19] M.S. Vivekanandan and Dr. C. Rajabhushanam, "Enabling Privacy Protection and Content Assurance in Geo-Social Networks", International Journal of Innovative Research in Management, Engineering and Technology, Vol 3, Issue 4, pp. 49-55, April 2018.

[20] Dr. C. Rajabhushanam, V. Karthik, and G. Vivek, "Elasticity in Cloud Computing", International Journal of Innovative Research in Management, Engineering and Technology, Vol 3, Issue 4, pp. 104-111, April 2018.

[21] K. Rangaswamy and Dr. C. Rajabhushanamc, "CCN-Based Congestion Control Mechanism In Dynamic Networks", International Journal of Innovative Research in Management, Engineering and Technology, Vol 3, Issue 4, pp. 117-119, April 2018.

[22] Kavitha, R., Nedunchelian, R., "Domain-specific Search engine optimization using healthcare ontology and a neural network backpropagation approach", 2017, Research Journal of Biotechnology, Special Issue 2:157-166

[23] Kavitha, G., Kavitha, R., "An analysis to improve throughput of high-power hubs in mobile ad hoc network", 2016, Journal of Chemical and Pharmaceutical Sciences, Vol-9, Issue-2: 361-363

[24] Kavitha, G., Kavitha, R., "Dipping interference to supplement throughput in MANET" , 2016, Journal of Chemical and Pharmaceutical Sciences, Vol-9, Issue-2: 357-360

[25] Michael, G., Chandrasekar, A.,'Leader election based malicious detection and response system in MANET using mechanism design approach", Journal of Chemical and Pharmaceutical Sciences(JCPS) Volume 9 Issue 2, April - June 2016

[26] Michael, G., Chandrasekar, A.,"Modeling of detection of camouflaging worm using epidemic dynamic model and power spectral density", Journal of Chemical and Pharmaceutical Sciences(JCPS) Volume 9 Issue 2, April - June 2016

[27] Pothumani, S., Sriram, M., Sridhar, J., Arul Selvan, G., Secure mobile agents communication on intranet,Journal of Chemical and Pharmaceutical Sciences, volume 9, Issue 3, Pg No S32-S35, 2016

[28] Pothumani, S., Sriram, M., Sridhar , Various schemes for database encryption-a survey, Journal of Chemical and Pharmaceutical Sciences, volume 9, Issue 3, Pg NoS103-S106, 2016

[29] Pothumani, S., Sriram, M., Sridhar, A novel economic framework for cloud and grid computing, Journal of Chemical and Pharmaceutical Sciences, volume 9, Issue 3, Pg No S29-S31, 2016

[30] Priya, N., Sridhar, J., Sriram, M. "Ecommerce Transaction Security Challenges and Prevention Methods- New Approach" 2016 ,Journal of Chemical and Pharmaceutical Sciences, JCPS Volume 9 Issue 3.page no:S66-S68 .

[31] Priya, N.,Sridhar,J.,Sriram, M."Vehicular cloud computing security issues and solutions" Journal of Chemical and Pharmaceutical Sciences(JCPS) Volume 9 Issue 2, April - June 2016

[32] Priya, N., Sridhar, J., Sriram, M. "Mobile large data storage security in cloud computing environment-a new approach" JCPS Volume 9 Issue 2. April - June 2016

[33] Anuradha.C, Khanna.V, "Improving network performance and security in WSN using decentralized hypothesis testing "Journal of Chemical and Pharmaceutical Sciences(JCPS) Volume 9 Issue 2, April - June 2016.

[34] Anuradha.C, Khanna.V, "A novel gsm based control for e-devices" Journal of Chemical and Pharmaceutical Sciences(JCPS) Volume 9 Issue 2, April - June 2016

[35] Anuradha.C, Khanna.V, "Secured privacy preserving sharing and data integration in mobile web environments " Journal of Chemical and Pharmaceutical Sciences(JCPS) Volume 9 Issue 2, April - June 2016.

[36] Sundarraj, B., Kaliyamurthie, K.P. Social network analysis for decisive the ultimate classification from the ensemble to boost accuracy rates 2016 International Journal of Pharmacy and Technology 8

[37] Sundarraj, B., Kaliyamurthie, K.P. A content-based spam filtering approach victimisation artificial neural networks 2016 International Journal of Pharmacy and Technology83.

[38] Sundarraj, B., Kaliyamurthie, K.P. Remote sensing imaging for satellite image segmentation 2016 International Journal of Pharmacy and Technology8 3.

[39] Sivaraman, K., Senthil, M. Intuitive driver proxy control using artificial intelligence 2016 International Journal of Pharmacy and Technology84.

[40] Sivaraman, K., Kaliyamurthie, K.P. Cloud computing in mobile technology 2016 
Journal of Chemical and Pharmaceutical Sciences92.

[41] Sivaraman, K., Khanna, V. Implementation of an extension for browser to detect vulnerable elements on web pages and avoid click jacking 2016 Journal of Chemical and Pharmaceutical Sciences92

\section{AUTHORS PROFILE}

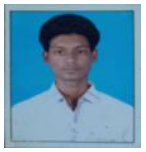

Sugumar V, Student, Department of IT, Bharath Institute of Higher Education and Research, Tambaram, India

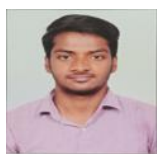

Aravindasamy R, Student, Department of Computer Science \& Engineering, Bharath Institute of Higher Education and Research, Chennai, India

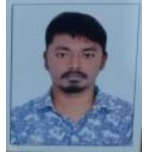

Jeffrin Rajan M, Student, Department of Computer Science \& Engineering, Bharath Institute of Higher Education and Research, Chennai, India

P. Kavitha, Department of IT, Bharath Institute of Higher Education and Research, Tambaram, India 